\title{
Archeology as a Metaphor in Contemporary Culture
}

\author{
Jacek Woźny \\ Kazimierz Wielki University, Poland
}

DOI: http://dx.doi.org/10.18778/1733-8077.17.1.3

\section{Keywords:}

Archeology; History

of Science; Metaphor;

Research Methods;

Contemporary Culture

\begin{abstract}
The scientific discipline of archeology has gone through various stages of its development and improvement of research methods. First, it was combined with ancient history and the history of art. In the mid-nineteenth century, the base of its chronology was on biblical events. Modernist archeology of the twentieth century focused on classifying monuments and reconstructing cultural processes. In the second half of the twentieth century, archeology inspired other disciplines of culture and science to "stratigraphically" look at their own history. In this way, the stratification of scientific thought (archeology of knowledge), the history of photography (archeology of photography), and the media (archeology of media) began to be analyzed. Archeology has become a cognitive metaphor in contemporary culture. Lack of knowledge of the theoretical and methodological achievements worked out by archaeologists may, after some time, lead to the trivialization and petrification of the archaeological metaphor, although today it still seems fresh and innovative for "archeology of media," "archeology of photography," or "archeology of modernism."
\end{abstract}

Jacek Woźny is a Professor of Humanities in the discipline of archaeology. His research interests concern the archeology of prehistoric beliefs and religions, the theory and methodology of archaeology, and the archaeology of the Polish lands. He is the author and editor of 20 monographs and 180 scientific articles. For example, he published the books: Symbolika wody w pradziejach Polski (Symbolism of Water in the Prehistory of Poland [1996]), Symbolika przestrzeni miejsc grzebalnych w czasach ciałopalenia zwłok na ziemiach polskich (Symbolism of the Space of Burial Sites in the Times of Burning Corpses in Poland [2000]), Czerwona ochra i ziarna zbóż: Symbolika odrodzenia zmartych w obrzedach pogrzebowych kultur archaic- znych międzymorza battycko-pontyjskiego (Red Ocher and Grains of Cereals. The Symbolism of the Revival of the Dead in the Funeral Rites of Archaic Cultures of the Baltic-Pontic Intermarium [2005]), and Archeologia kamieni symbolicznych. Od skały macierzystej do dziedzictwa przodków (The Archeology of Symbolic Stones. From Bedrock to Ancestral Heritage [2014]). Jacek Woźny is the Rector of the Kazimierz Wielki University in Bydgoszcz for the second time (2016-2020, 2020-2024). He is the head of the Department of Ancient Archaeology and Ancient History of the University of Kazimierz Wielki in Bydgoszcz.

email address: wozja@ukw.edu.pl 


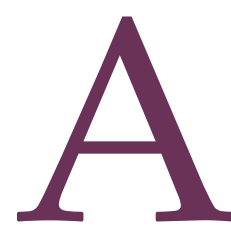

gainst the background of the study of the condition of contemporary archeology, the words of Bjørnar Olsen (2013:9 [trans. JW]) sound original, who in 2010 stated that "Archeology, as a term, has become a popular and even abused phrase among philosophers, psychologists, sociologists, and literary scholars. However, few of them, fascinated by the metaphorical bearing capacity of the word, bothered to seriously consider what contribution archeology could have in solving their problems." It is worth attempting to explain why culture studies and representatives of other humanistic and social disciplines do not notice the theoretical achievements of contemporary archeology, while archaeologists are not interested in using the name of their discipline in contemporary humanities (Minta-Tworzowska 2015:21-37).

Edmund Husserl formulated the thesis that the view of prehistory opens our own present. The cognitive subject is not only determined by history, but they determine it themselves. The past in this sense permeates the present, is subject to ordering and evaluation according to our own criteria, and not the principles used by the societies and cultures constituting the subject of our study. An analogical specificity of looking at artifacts from the past characterized all previous generations and cultural traditions (Mamzer 1997:38-41). A reflection on this issue creates an opportunity to explain the presence of archeology as a metaphor for studying the past, used in contemporary culture (Olsen 2013:8-9).

\section{The Transformation of the Cognitive Status of the Metaphor}

The introduction to this, however, is to determine the transformation of the cognitive status of the metaphor. In traditional rhetoric, the metaphor is classified as a clue, that is, as one of the figures distinguished according to the criterion of a specific modification of meaning in the use of words. In Aristotle's Poetics, we read that the metaphor consists of the transfer of a foreign meaning to the name. Cicero and Quintilian wrote that the metaphor is simply a shortened comparison that does not add new information about reality to the discourse (Ricoeur 1989:126-127). The rationale of classical rhetoric has been questioned by contemporary semantic analysis of metaphors, represented in the works of such authors as I. A. Richards, Max Black, Monroe Beardsley, and Philip Wheelwright. Gilbert Ryle said the metaphorical expression is about revealing the association where there is no relationship from the colloquial point of view. Through this apparent misunderstanding, a new, previously unrecognized, semantic relation between the terms is established so that the current classification system is ignored or which it did not allow. Two classes of meanings, so far distant, are suddenly put together: the action of similarity, in this case, consists in grasping the closeness of what was previously not compared (Ricoeur 1989:131).

The description of the role of similarity in metaphorical expressions results in a further reservation in relation to the rhetorical concept of a metaphor. In classical terms, it was based on simply replacing one word with another. On the other hand, the contemporary theory explaining the metaphor through the semantic tension reveals the emergence of a new sense that embraces the whole sentence. A metaphor is more like a solution to the puzzle than a simple association based on similarity (Ricoeur 1989:132-133). At least two basic points, therefore, discern the contemporary approach to metaphor from the one cultivated by classical rhetoric. First of all, the metaphor 
is no longer a clue based on a word or name, so it is not just a denominational operation. Secondly, the contemporary approach does not support the concept that recognizes the idea of similarity between the replaced names as a constitutive property of the metaphor. A metaphor can be treated as a rhetorical, literary, and poetical concept, but it can also be perceived in a context that makes it an epistemological category. This is how it is qualified by philosophical new rhetorics, logical grammar, and hermeneutics. In their light, the notion of metaphor assimilates the findings of post-positivist epistemologies, first of all, the problems of explaining and modeling, as well as the problems typical of anti-positivist currents in reflection on science (Wrzosek 1995:26-29). These problems are particularly important when humanistic or social disciplines reach for the "metaphor of the archaeological site," but do not declare methodological sources of their decisions (e.g., Archeology of Transformation: Gender War in an Intersectional Perspective-Museum of Modern Art in Warsaw [https://artmuseum.pl/pl/wydarzenia/archeologia-transformacji-wojna-o-gender-jako-archeologiczne, retrieved March 25, 2019]).

\section{The Paradigms of the Main Trends of Archeology}

In the mid-nineteenth century, archeology was combined with other humanistic disciplines, accompanied by the objectification of the past, because it was contrasted with the life and times of nineteenth-century prehistorians (Mamzer 1997:39). At that time, it was believed that prehistory is the source of contemporaneity. Today's methodology recognizes our creative role in attributing content to old artifacts (Olsen 2013:11). The nineteenth-century archeology focused on the visible traits of discovered things and objects, striving for a universal system of their periodization (Hensel 1983:48-49). At that time, the genetic metaphor predominated, proving that all observed phenomena in the world of nature and culture have their sources in the past (Renfrew and Bahn 2002:24-25). The nineteenth-century paradigm of ethnogenesis and the related problem of the origin of Slavs and Germans is still the main driving force of Central European archeology (Mamzer 1997:41-42).

Modernist archeology shaped in the twentieth century created a model of science that seemed a universal paradigm of humanities (Mamzer 1997:14). According to Witold Hensel's (1983) opinion from 1972,

we will give meaning to archeology most accurately if we state that it deals with uncovering, mainly by means of excavation methods, sources of the past and their scientific registration and evaluation...This character is combined with its function in the field of reconstruction of economic, cultural, social, and political relations. In other words, archeology is used for all branches of science whose aim is to recreate a part or the whole of the historical process...The scope, research goals of archeology, and its place in the family of other sciences are...clear and qualify it as a discipline serving to learn about the past, and at the same time serving to shape the future...None of the most interesting theoretical concepts can replace the knowledge resulting from a concrete knowledge of facts. [pp. 13-27 (trans. JW)]

While the entire archeology of the first half of the twentieth century was influenced by cultural and historical archeology, the subsequent decades have resulted in the development of the so-called New Archeology, Marxist and Neo-Marxist, and structural archeology (Marciniak 2012:32-64). The development of archaeological subdisciplines determined 
the multiplicity of topics currently considered as "archaeological":

starting with the analysis of the material culture of early hominids, through the reconstruction of the beliefs of archaic societies or the formation of the first civilizations, and ending with judicial archeology or the mechanisms of consumption in modern cities... The attempt to define the thematic scope of archeology is hindered by the fact that the conceptual network is imposed on a cultural reality that is continuous, flexible, and changing over time. This variability concerns both the analyzed reality itself...and the disciplines dealing with it, usually with overlapping fields of research interest. [Cyngot and Zalewska 2012:193194 (trans. JW)]

The paradigms of the main trends of archeology in the second half of the twentieth century often coincided with the leading directions of humanistic thought, such as the idea of cultural process, behavioralism, cognitivism, antagonistic visions of the world, cultural codes structure, and others (Marciniak 2012:39-64). Researchers have turned to culture, looking for universal content that functions in all communities (Domańska 1997:65). New branches of archeology appeared and became active, such as archeology of everyday life, consumption archeology, death archeology, symbolic archeology, landscape archeology, and many more. All of them are looking for new, non-classical metaphors for thinking about the past, getting rid of the burden of the current paradigm of prehistory as a stratigraphically recorded sequence of events, perceiving it by the similarity of overlapping processes and cultural changes (Minta-Tworzowska 2015:32).

The transformation of archeology in the postmodern trend led to the abandonment of the modernist model, whose main construction axis was a metaphor of progress, unifying prehistoric reality.

Post-modernity assumes...a completely different structure of the research field than in the case of the modernist history of civilizational progress...Thus, every examination of past reality means...exclusively evocation, that is, the invocation of such a reality as it is of significance to us today. [Mamzer 1997:15-16 (trans. JW)]

According to Dorota Cyngot, in the post-modern world, the very concept of "archeology" is becoming more and more often a metaphor for various fields of knowledge and everyday life, indicating the direction of the search for beginnings, origins, and roots. Michel Foucault used such comparisons in his "archeology of knowledge," as well as "archeology of medical examination," and "archeology of humanities." They were followed by other metaphors built in non-archeological discourses by other authors: "archeology of photography," "archeology of music," up to "spiritual archeology" or "archeology of subconscious," encountered in contemporary essay writing and fiction. Expanding and crossing interdisciplinary boundaries means that in relation to some phenomena in the field of what is currently referred to as archeology, one may wonder how much this use takes on a metaphoric character and what it actually means (Cyngot 2012:799).

\section{The Perspective of Cultural Memory}

A clue that can lead to the explanation of the tendency of using archaeological metaphor outside the primary research domain of this discipline is the perspective of cultural memory. There are more and more supporters of a thesis about a growing bloom of remembrance and memory, which would 
signal equally important changes in the humanities as earlier, modernist phrases: linguistic, spatial, or pictorial (Saryusz-Wolska 2009:7). Jan Assmann (2009:69 [trans. JW]) stated that "thinking is based on abstraction, and remembering-on particulars." Ideas must gain material expression to become objects of memory. From mutual interpenetration of concepts and experiences, the so-called figures of memory are created. Their specificity is determined by three characteristics: a specific reference to space and time, a reference to a specific group, and reconstruction (Assmann 2008:53-54). It is easy to see the similarity of memory figures to some research paradigms of archeology.

On the one hand, as a result of their cognitive activity, archaeologists restore (in social/research awareness) what escapes historical consciousness, which is often unconscious. On the other hand, recalling the memory of the past, extracting knowledge about it to the light, showing what is invisible or unclear by itself, is done at the expense of physical destruction or decomposition of the message itself, created in the post-deposition/stratification process. [Cyngot and Zalewska 2012:199 (trans. JW)]

To indicate the essential features of social-cultural memory, reference should be made to the characteristic places and artifacts that designate it. Cultural memory is based not only on written messages, "but also on dances, games, rites, masks, pictures, rhythms, melodies, decorations, weapons, et cetera, which are...intense forms of self-perception and self-reliance of the social group" (Assmann 2009:92 [trans. JW]).

The "contemporary offensive of memory" (Le Goff 2007:105) is based on many media, among which memories and biographies play an important role
(Saryusz-Wolska 2009:35). Autobiographical memory reaches "without difficulty to the existing elements of reality, which-from the perspective of the present-seem to 'fit' into their own past" (Welzer 2009:57 [trans. JW]). An interest in memory and the continuation of the past also increased in archeology as a scientific discipline.

Contrary to romantic and modernist ideas, archaeologists do not discover the past, but work within the past that is in the present...The archaeological site is truly disordered; it consists of a palimpsest of structures built in different periods...These are places that do not fit into the dreams of modernity or historicism about the completeness, order, and refined time. [Olsen 2013:197 (trans. JW)]

Since the changes in the fate of things in culture result from the selective memory of the past, it was proposed to study biographies of individual artifacts. According to the ideas of Igor Kopytoff and Bjørnar Olsen, objects have always been associated with society in various ways. Analysis of the biographies of selected artifacts is also a study of the communities in which they were used (Iwaniszewski 2012:276).

In addition to the solidity brought by things in everything that we have learned to think of as social and cultural, they allow us to obtain yet another closely related result: the gathering or embedding of the past. The past is not left behind, but patiently gathers and arranges into what we conveniently call the present. [Olsen 2013:263 (trans. JW)]

In a novel way, Marta Raczyńska applied these concepts in contemporary Polish cultural anthropology. In her book, Czas uwarstwiony na gąsawskim poddaszu [Time Stratified in the Gasawa Attic], the introduction 
of the archaeological metaphor of "temporal layers" and an attempt to look at the attic as a representation of stratified memory have made this report a peculiar story about the relationship of the inhabitants of Gąsawa with their past: family, home, and also having a local dimension; a past that can be learned through memorabilia, as well as ordinary "junk" (Raczyńska 2016).

\section{The Analysis of the Contexts of the Use of the Archaeological Metaphor}

There are at least a few non-archeological examples of the use of "stratigraphic" analysis of the achievements of a given field of culture or science investigating the accumulation of its achievements and concepts, from the beginnings to the present day. One of such projects was created by Jerzy Lewczyński, an artist distinguished for post-war Polish photography. Since the late 1960s, he has achieved his own individual style, full of references to amateur photography, the world of childhood, found negatives and prints, which in the 1990s included in his original concept of "archeology of photography." He called it "activities, the aim of which is to discover, study, and comment on events, facts, situations happening in the so-called photographic past. Thanks to photography, the continuity of visual contact with the past creates opportunities to broaden the influence of old cultural and creative layers on today's" (trans. JW [https://culture.pl/pl/wydarzenie/jerzy-lewczynski-archeologia-fotografii\#, retrieved December 20, 2020]). On the basis of Jerzy Lewczyński's concept, in 2008, the Archaeology of Photography Foundation was created, protecting the legacy of photographers and disseminating knowledge about the history of Polish photography in the form of a special archive (see: faf.org.pl/strona/gmuranowska144.pdf, retrieved December 20,
2020). The archeology of photography is looking for manifestations of the existence of this field of creativity at all stages of its development. It has strong support in the photography philosophy of Vilem Flusser. According to him,

we have witnessed two fundamental turning points in the history of mankind: the first was associated with the invention of linear writing, the second with the invention of technical images. The first technical picture was a photographic image, therefore attempts to explain the phenomenon of photography are at the same time attempts to understand the basic changes that are taking place in the modern world. [Flusser 2015:17 (trans. JW)]

Just as the memory recorded in images is important and archived in the project of the Archeology of Photography Foundation (see: faf.org.pl/strona/ gmuranowska144.pdf, retrieved December 20, 2020), the performative program "Body Archive" has significant cognitive value, which was termed "archeology of dance."

Choreographers become a kind of archaeologists who keep their excavations in the reservoir of cultural memory. Their purpose is to extract from the past "the products" of the works of their predecessors. However, their task is slightly more difficult than for historians or real archaeologists, because the specificity of dance and theater is the lack of material products of the activities of actors/dancers and directors. A void remains in the place of the original...[How to deal with it? There are several ways,] one can search for traces and try to reconstruct the works of your predecessors in one's own way. Sometimes original works can be recreated... Sometimes it is much more inspiring to experience the choreography process itself than to reconstruct it. [Juźwik 2014-2015:24 (trans. JW)] 
In this respect, discovering the historical stratigraphy of the history of dance corresponds to the concept of archeology of knowledge of Michel Foucault. He stated that this archeology "does not try to restore what could have been thought, wanted, intentional, experienced, or desired by people at the moment when they spoke the discourse...It is nothing more...than a rewriting...of what has already been written" (Foucault 1977:173 [trans. JW]).

A fundamental role in the implementation of the "Body Archive" project plays on the idea of the cultural memory, present in contemporary humanities and archeology.

It turns out that the human body can also become "a storehouse" of what man has remembered in the entire experience of reality. Social and political events also (in a sense) determine the memory of the body. It is not only the imitative presentation of movement exercises, but also presents the sensual world of a man who functions in a given culture...What is happening in the reality that surrounds us has an impact on how our body reproduces, what our movement memory is. [Juźwik 2014-2015:29 (trans. JW)]

Similar concepts are used in artistic multimedia projects that refer to the values of the human body. In the "War on Gender" exhibition at the Museum of Modern Art in Warsaw, Ewa Charkiewicz used a metaphor of the archaeological site, where the layers are removed, the heterogeneous elements exposed, and the relationships sought between them, to reveal how the darkening and masking of the gender/ power relations were organized in discourses about family, equality, and anti-discrimination (see: https:// artmuseum.pl/pl/wydarzenia/archeologia-transformacji-wojna-o-gender-jako-archeologiczne, retrieved March 25, 2019). In the field of contemporary art,
Mirosław Bałka used the same aspect of archeology. When creating his works, he emphasizes the role of the memory of things. What is important to him is private archeology. The artist thus finds "archaeological sites" in both his own and collective memory (Delikta 2018).

"Archeology of photography," "archeology of dance," and other artistic activities help to reveal the layers of cultural memory and archive achievements within particular disciplines. Memory constantly adapts the retained knowledge to the requirements of modern times. In this way, a balanced relation between memory and forgetfulness is ensured, while the historical build-up of various approaches to media and memory implementation is called "media archeology," understood as the sum of cultural studies and research on media history and ethnology (Butzer 2009:195-199). Siegfried Zielinski recognized that its predominant goal is to constantly find the New in the Old.

How can an object that is still so new be attributed to archeology? Media, technically and culturally complex systems, have existed...only for half a century... The individual devices for communication, listening, and seeing, in which technical means and instruments were used, are much older...Their origin and improvement should be connected with times much earlier than the $19^{\text {th }}$ century. In that century, the telegraph, telephone, photography, and cinema became objects of general use and industrial production. However, the ideas and concepts that inspired these communication techniques send us many years back. The research attitude that emerges in this way can be called a paleontological attitude. Similarly to the most advanced researchers of our planet Earth who, in their tireless search, do not accept any granite layer, through which they would not be able to break 
through to even older evidence of its existence, also we do not stop at the time of the explosion of communication technologies of the industrial era. [Zielinski 2010:IX-XI (trans. JW)]

This attitude is currently gaining new supporters. "The increasingly popular position of media archeology requires...searching for older works, undiscovered by literary scholars, often carried out by visual artists, filmmakers, creators testing various media (from the film, through books, to computers), or computer geeks operating in Poland in the 1980s and 1990s within a framework of demoscene" (Żuk Piwkowski and Marecki 2014:98).

Exploratory activities are even carried out on YouTube.

Of course, talking about the archaeological function of YouTube is only a metaphor. Recalling archeology in the context of the website, however, better describes the observable trend, in which specific archival resources (fragments of films or even little-known videos from many years ago) are discovered and brought back to life after years of oblivion. Just as an archaeologist discovers forgotten artifacts, bringing them to the surface and transferring them to museums, where thousands of people watch them, the YouTube infrastructure identifies and promotes films from many years ago. [Wilkowski 2009 (trans. JW)]

In this situation, a clear similarity between the two conceptual strings is created: Archeology-Artifacts-Museums-Viewers and Internet-Movies/ Texts-YouTube-Internet users.

Media archeology should not be confused with archeology as a discipline. When media archaeologists say they are conducting "excavations" of media and cultural phenomena, this word should be understood in a specific way. Media archeology deals with both text, visual, and audio archives, as well as collections of artifacts while stressing the discursive and material aspects of cultural products. Its research smoothly passes between disciplinary boundaries, which allows one to move freely in the field of humanities and social sciences, and to look into fine arts. Media archeology is rooted in a deep distrust of dominant historical narratives, which brings it closer to the practice of new historicism. According to the creators and representatives of this discipline, archeology, unlike history, refers to what really exists, what remains of the past in the shape of archaeological layers present in technologies. Thus, media archaeologists are trying to discoveror rather dig out-what is hidden under historical narratives, revising artifacts to show previously unseen connections and interruptions (Maryl 2014). In this respect, the use of a metaphorical expression revealed connections where colloquial seeing did not see any relationship. Through this seeming misunderstanding, a new, previously unrecognized, semantic relation was established between the terms that the current classification system of sciences ignored, as Paul Ricoeur predicted in his hermeneutics of metaphor (Ricoeur 1989:124-133).

The currently developing field called media archeology seems to follow the path delineated by Michel Foucault- "the last historian, or the first archaeologist" (Maryl 2014:189 as cited in Kittler 1999:5). In the concept of Michel Foucault, archeology is a metaphor for research on the stratigraphy of discourses. This philosopher proposed designating the field, which he created by the name "archeology of knowledge," as a synonym of discovering something hidden. Following Gaston Bachelard, he most probably wanted to express his perspective on the history of 
science through the prism of "cuts," "thresholds," and discontinuation, which accompany classical archeologists in research. The Foucauldian archaeologist should dig into unconscious forms of thinking, taking off layers of elementary discourse units, such as statements (Topolski 1977:5-21). Michel Foucault's theory is constantly updated.

The concept archailogia contains not only the old, the original (archaios), but also the activities of governance, domination (archein), as well as the noun archos, the leader...In the discussion of Foucault's concept of archeology of knowledge...Rudi Visker used the name An-archeologie to describe a method that could not be refocused by any reference to the identification potential of a unified object of original experience...Wolfgang Ernst used the term Anarchäeologie in another interesting sense: as an opposing movement to excavation and uncovering. [Zielinski 2010:37 (trans. JW)]

An overview of the contexts of the use of the archaeological metaphor indicates their limited systematics. We find descriptions of "waste and debris of past historicism in modernism from the beginning of the $20^{\text {th }}$ century as if it cited prehistory" (Rejniak-Majewska 2017:153 [trans. JW]). The "pre-history of culture 2.0" is mentioned by analysts of new media and digital technologies (Filiciak and Tarkowski n.d.). In the analyses of the conceptualization of the concept of "text" and the transformation of thinking styles in literary studies, "archaeological or detective investigations serve to restore the whole and reach the perpetrator. This whole is always concrete and has a specific author" (Jarnicki 2014:181 [trans. JW]). The literary study of Bruno Schulz's forgotten text Lilien is called the "archeology of Polish-Jewish modernism" because, like archeology, it discovers something that has disappeared from the minds of readers (Underhill 2016:656). In addition to the "excavation" metaphor, concepts of "tem- poral layers" (Raczyńska 2016), "archeological sites" (Delikta 2018; https://artmuseum.pl/pl/wydarzenia/ archeologia-transformacji-wojna-o-gender-jako-archeologiczne, retrieved March 25, 2019), or "forgotten artifacts" (Wilkowski 2009) are also used.

\section{Conclusion}

Retrospective studies of Michel Foucault, Siegfried Zielinski, Wolfgang Ernst, Rudi Visker, and others, consisting in the search for the identity of specific problems, starting from the situation found by the researcher, culturally diverse to a uniform, even culturally homogeneous reality located lowest in prehistory, is "stratigraphic research" for which archeology is a handy operational metaphor (Mamzer 2004:205). Unfortunately, they are based on the traditional understanding of this discipline and do not use the semantic potential contained in the non-classical concept of metaphor, used by contemporary historiography and archaeological theory (Wrzosek 1995:29-30). It should also be emphasized that they refer to the classical, banal "stratigraphic" metaphor (Wrzosek 1995:30), while archeology followed the modern theory that explains the metaphor through the semantic tension between two terms (Ricoeur 1989:132-133). Referring to Shanks's comparison of the development of archeology with a growing tree, culture studies, philosophers, sociologists, media experts, and other researchers reached in their metaphors for the excavational "roots" of archeology, but they did not notice a solid "trunk" of data synthesis and processing, "branches" of interpretation, and, above all, the tangled and ever-growing "branches" of new scientific theories and approaches (Minta-Tworzowska 2015:21-37). The inspiration for asking questions two decades earlier about the place and role of archeology in contemporary humanities was an attempt to assess the importance of this dis- 
cipline against other sciences about the past and the desire to reflect on the causes of the increasingly widening gap between archeology and contemporary humanities (Ostoja-Zagórski 1997:6-9). Since then, many subsequent debates have been conducted, important collective publications have been published (e.g., Tabaczyński et al. 2012), and monographic ones (e.g., Mamzer 2004). Among other things, it comes to the conclusion that since the birth of this discipline

\section{References}

Assmann, Jan. 2008. Pamięć kulturowa. Pismo, zapamiętywanie i polityczna tożsamość w cywilizacjach starożytnych [Cultural Memory. Writing, Remembering, and Political Identity in Ancient Civilizations]. Warsaw: Wydawnictwo Uniwersytetu Warszawskiego.

Assmann, Jan. 2009. "Kultura pamięci [Culture of Memory]." Pp. 59-99 in Pamięć zbiorowa i kulturowa [Collective and Cultural Memory], edited by M. Saryusz-Wolska. Warsaw: Universitas.

Butzer, Günter. 2009. “Metaforyka pamięci [Metaphors of Memory]." Pp. 185-209 in Pamięć zbiorowa i kulturowa [Collective and Cultural Memory], edited by M. Saryusz-Wolska. Warsaw: Universitas.

Cyngot, Dorota. 2012. "Archeologia a językoznawstwo [Archeology and Linguistics]." Pp. 791-802 in Przeszłość społeczna. Próba konceptualizacji [Social Past. An Attempt at Conceptualization], edited by S. Tabaczyński et al. Poznan: Wydawnictwo Poznańskie.

Cyngot, Dorota and Anna Zalewska. 2012. "Zmienność i dynamiczność podziałów tematycznych w archeologii [Changeability and Dynamics of Thematic Divisions in Archeology]." Pp. 193-206 in Przeszłość społeczna. Próba konceptualizacji [Social Past. An Attempt at Conceptualization], edited by S. Tabaczyński et al. Poznan: Wydawnictwo Poznańskie.

Delikta, Wojciech. 2018. "Prywatna archeologia [Private Archeology]." Retrieved March 25, 2019 (https://www.vogue.pl/a/ prywatna-archeologia).

Domańska, Ewa. 1997. “Tekstualizacja archeologii (od Barthesa do Hoddera) [Textualization of Archeology (from Barthes to of science in the mid-nineteenth century, through subsequent stages of its biography, archeology has reached the multitemporal present and has become a way of thinking about the past in the non-archeological fields (Kobiałka 2016:6). The limited use of the "archeological" metaphor in contemporary culture may, however, lead to its banalization and petrification after some time, although it still seems fresh and innovative today (Wrzosek 1995:29).

Hodder)]." Pp. 65-77 in Jakiej archeologii potrzebuje wspótczesna humanistyka? [What Archeology Does Contemporary Humanities Need?], edited by J. Ostoja-Zagórski. Poznan: Instytut Historii UAM.

Filiciak Mirek and Alek Tarkowski. n.d. "Archeologia przyszłości [Archeology of the Future]." Retrieved March 25, 2019 (https://www. dwutygodnik.com/artykul/1202-archeologia-przyszlosci.html).

Flusser, Vilém. 2015. Ku filozofii fotografii [Towards the Philosophy of Photography]. Warsaw: Aletheia.

Foucault, Michel. 1977. Archeologia wiedzy [The Archeology of Knowledge]. Warsaw: PIW.

Hensel, Witold. 1983. Archeologia żywa [Living Archeology]. Warsaw: Wydawnictwo Artystyczne i Filmowe.

Iwaniszewski. Stanisław. 2012. "Archeologia czasu [Archeology of Time]." Pp. 273-283 in Przeszłość społeczna. Próba konceptualizacji [Social Past. An Attempt at Conceptualization], edited by S. Tabaczyński et al. Poznan: Wydawnictwo Poznańskie.

Jarnicki, Paweł. 2014. Metaforyczne konceptualizacje pojęcia "tekstu" a przemiany stylów myślowych w literaturoznawstwie [Metaphorical Conceptualizations of the Concept of "Text" and Changes in Thought Styles in Literary Studies]. Wroclaw: Wydawnictwo Fundacji "Projekt Nauka".

Juźwik, Magdalena. 2014-2015. “Cielesne czy bezcielesne? Pamięć ciała w teatrze fizycznym [Corporeal or Incorporeal? Body Memory in Physical Theater]." Literaturoznawstwo 8-9:21-30. 
Kobiałka, Dawid. 2016. “UrbEx: archeologiczny flaneuryzm a multitemporalność dziedzictwa [UrbEx: Archaeological Flaneurism and Multitemporality of Heritage]." Biografia Archeologii 2(1):3-12.

Le Goff, Jacques. 2007. Historia i pamięć [History and Memory]. Warsaw: Wydawnictwo Uniwersytetu Warszawskiego.

Mamzer, Henryk. 1997. "Pytanie o archeologię [Question about Archeology]." Pp. 13-50 in Jakiej archeologii potrzebuje wspótczesna humanistyka? [What Archeology Does Contemporary Humanities Need?], edited by J. Ostoja-Zagórski. Poznan: Instytut Historii UAM.

Mamzer, Henryk. 2004. Archeologia i dyskurs [Archeology and Discourse]. Poznan: IAE PAN.

Marciniak, Arkadiusz. 2012. "Paradygmaty badawcze w archeologii [Research Paradigms in Archeology]." Pp. 29-83 in Przeszłość społeczna. Próba konceptualizacji [Social Past. An Attempt at Conceptualization], edited by S. Tabaczyński et al. Poznan: Wydawnictwo Poznańskie.

Maryl, Maciej, 2014. "Fonograf Abrahama - w stronę archeologii literatury [Abraham's Phonograph-Towards the Archeology of Literature]." Teksty Drugie 3(147):179-193.

Minta-Tworzowska, Danuta. 2015. “Czy współczesna i przyszła archeologia będzie 'potrzebowała' teorii? [Will Contemporary and Future Archeology 'Need' a Theory?].” Archeologia Polski LX:21-37.

Olsen, Bjørnar. 2013. W obronie rzeczy. Archeologia i ontologia przedmiotów [In Defense of Things. Archeology and Ontology of Objects]. Warsaw: Instytut Badań Literackich PAN.

Ostoja-Zagórski, Janusz, ed. 1997. Jakiej archeologii potrzebuje współczesna humanistyka? [What Archeology Does Contemporary Humanities Need?]. Poznan: Instytut Historii UAM.

Raczyńska, Marta. 2016. Czas uwarstwiony na gasawskim poddaszu. Antropologiczny szkic o przestrzeni, przedmiotach i obcowaniu z przeszłościa [Time Stratified in the Gasawa Attic. An Anthropological Sketch about Space, Objects, and Communing with the Past]. Cracow: Wydawnictwo Libron.

Rejniak-Majewska, Agnieszka. 2017. “Wizualne archeologie nowoczesności: Walter Benjamin i Sigfried Giedion [Visual Archeologies of Modernity: Walter Benjamin and Sigfried Giedion]." Filo-Sofija 38:149-156.
Renfrew, Colin and Paul Bahn. 2002. Archeologia. Teorie, metody, praktyka [Archaeology. Theories, Methods, Practice]. Warsaw: Prószyński i S-ka.

Ricoeur, Paul.1989. Jezyk, tekst, interpretacja [Language, Text, Interpretation]. Warsaw: PIW.

Saryusz-Wolska, Magdalena. 2009. “Wprowadzenie [Introduction]." Pp. 7-38 in Pamięć zbiorowa i kulturowa [Collective and Cultural Memory], edited by M. Saryusz-Wolska. Warsaw: Universitas.

Tabaczyński, Stanisław et al. 2012. Przeszłość społeczna. Próba konceptualizacji [Social Past. An Attempt at Conceptualization]. Poznan: Wydawnictwo Poznańskie.

Topolski, Jerzy. 1977. “Wstęp [Introduction].” Pp. 5-26 in Archeologia wiedzy [The Archeology of Knowledge], M. Foucault. Warsaw: PIW.

Underhill, Karen. 2016. “Bruno Schulz, E.M. Lilien i archeologia polsko-żydowskiego modernizmu [Bruno Schulz, E.M. Lilien and the Archeology of Polish-Jewish Modernism]." Ruch Literacki LVII(6[339]):656-680.

Welzer, Harald. 2009. "Materiał, z którego zbudowane są biografie [The Material from which the Biographies Are Made]." Pp. 39-57 in Pamieć zbiorowa i kulturowa [Collective and Cultural Memory], edited by M. Saryusz-Wolska. Warsaw: Universitas.

Wilkowski, Marcin. 2009. "YouTube i historia. Artykuł w 'Kulturze Popularnej' [YouTube and History. Article in 'Kultura Popularna'].” Retrieved March 25, 2019 (historiaimedia.org/2009/09/12/youtube-i-historia-artykul-w-kulturze-popularnej/index.html).

Wrzosek, Wojciech. 1995. Historia, kultura, metafora. Powstanie nieklasycznej historiografii [History, Culture, Metaphor. The Rise of Non-Classical Historiography]. Wroclaw: Wydawnictwo Leopoldinum Fundacji dla Uniwersytetu Wrocławskiego.

Zielinski, Siegfried. 2010. Archeologia mediów [Media Archeology]. Warsaw: Oficyna Naukowa.

Żuk Piwkowski, Józef and Piotr Marecki. 2014. “Księga Słów Wszystkich, czyli archeologia mediów po polsku (wywiad) [The Book of All Words, or Media Archeology in Polish (Interview)]." Przegląd Kulturoznawczy 1(19):98-105.

\section{Citation}

Woźny, Jacek. 2021. “Archeology as a Metaphor in Contemporary Culture.” Qualitative Sociology Review 17(1):28-38. Retrieved Month, Year (http://www.qualitativesociologyreview.org/ENG/archive_eng.php). DOI: http://dx.doi.org/10.18778/1733-8077.17.1.3 